\title{
IDENTIFIKASI FENOTIPIK GALUR-GALUR KEDELAI TERHADAP KETAHANAN SERANGAN HAMA ULAT GRAYAK (SPODOPTERA LITURA F.)
}

\author{
Gatut Wahyu Anggoro Susanto \& Moh. Muchlish Adie \\ Balai Penelitian Tanaman Aneka Kacang dan Umbi, Malang, Jawa Timur \\ Jl. Raya Kendalpayak Km 8, Desa Kendalpayak, Kecamatan Kedungkandang, Kabupaten Malang \\ E-mail: gatut_wahyu@yahoo.com
}

\begin{abstract}
Phenotypic identification of soybean lines against armyworm pest resistance (Spodoptera litura $\boldsymbol{F}$ ). This research consisted of two parts which aimed to find out the intensity of damage to the leaves and the influence of soybean on the biological aspect of armyworms. The materials tested were Shr/W-C-60, Aochi/Wil-60, 9837/K-D-8-185, 9837/K-D-3-185-95, W/9837-D6-220, 9837/K-D-3-185-82, 9837/W-D-5-211, GI, G100H breeding lines and Wilis varieties. The research was conducted at a Balitkabi screenhouse in February 2011, using randomized block design and each treatment was replicated three times. The planting media were plastic pots (diameter $18 \mathrm{~cm}$ ) filled with earth, two seeds per pot were planted and intensively raised. When the plants were 27 days old after planting, at each replication consisting of 10 materials, they were covered with gauze cages $(2 \times 2 \times 2 \mathrm{~m})$. Then the plants in each pot was infested with 10 instar I armyworm larvae. The other part of research was carried out in Balitkabi Breeding Improvement Laboratory. For testing purposes, there was a need for a third nodal leaf of soybean aged 27 days after planting in each tested material. The research used a completely randomized design each treatment was replicated three times. One nodal leaf in each material was placed in a petri dish $15 \mathrm{~cm}$ in diameter, which was coated with moist filter paper, and this was later called treatment. Each treatment was infested with one instar I armyworm larva. The result of research indicated that an assessment of soybean resistance to armyworms could be made from the density of the trichome and/or the length of the trichome on the leaves. The $\mathrm{G} 100 \mathrm{H}$ breeding line was found to be resilient with its characteristics of having dense trichome $\left(25 / 4 \mathrm{~mm}^{2}\right)$ and long trichome $(1.1 \mathrm{~mm})$.
\end{abstract}

Key words: caterpillar army worm, soybean, trichoma

\section{ABSTRAK}

Identifikasi fenotipik galur-galur kedelai terhadap ketahanan serangan hama ulat grayak (Spodoptera litura F). Penelitian terdiri dua bagian yang bertujuan untuk mengetahui intensitas kerusakan daun dan pengaruh kedelai terhadap aspek biologi ulat grayak. Materi yang diuji adalah galur Shr/W-C-60, Aochi/Wil-60, 9837/K-D-8-185, 9837/K-D-3-185-95, W/9837-D-6-220, 9837/K-D-3-185-82, 9837/W-D-5-211, GI, G100H dan varietas Wilis. Penelitian dilakukan di rumah kasa Balitkabi pada Februari 2011, dirancang menggunakan acak kelompok setiap perlakuan diulang tiga kali. Media tanam pot plastik (diameter $18 \mathrm{~cm}$ ) yang diisi tanah, ditanam dua biji/pot dan dipelihara secara intensif. Saat tanaman berumur 27 hari setelah tanam (HST), pada setiap ulangan yang terdiri dari 10 materi disungkup dengan kurungan kasa $(2 \times 2 \times 2 \mathrm{~m})$. Selanjutnya tanaman pada masingmasing pot diinfestasi dengan larva ulat grayak instar I sebanyak 10 ekor. Penelitian lainnya dilakukan di Laboratorium Pemuliaan Balitkabi. Untuk pengujiannya dibutuhkan daun buku ketiga kedelai yang berumur 27 HST pada masing-masing materi yang diuji. Penelitian dirancang menggunakan acak lengkap yang diulang tiga kali. Satu daun buku ketiga pada setiap materi ditempatkan pada cawan Petri berdiameter $15 \mathrm{~cm}$ yang telah dilapisi kertas saring yang basah air (lembab), dan ini kemudian disebut sebagai perlakuan. Setiap perlakuan diinfestasi larva ulat grayak instar I sebanyak satu ekor. Hasil penelitian menunjukkan penilaian ketahanan kedelai terhadap ulat grayak dapat ditilik dari kerapatan trikoma dan atau panjang trikoma daun. Galur G100H dinilai tahan dengan karakteristik trikoma padat $\left(25 / 4 \mathrm{~mm}^{2}\right)$ dan panjang $(1,1 \mathrm{~mm})$.

Kata kunci: kedelai, trikoma, ulat grayak

\section{PENDAHULUAN}

Serangan hama merupakan salah satu masalah penting budidaya kedelai. Ulat grayak (Spodoptera litura F.) merupakan serangga hama yang bersifat polifag (Ravishankar \& Venkatesha, 2010) sehingga hama tersebut memiliki penyebaran dan kisaran inang yang cukup luas. Di Indonesia ulat grayak merupakan hama pemakan daun utama pada tanaman kedelai (Arifin \& Koswanudin, 2010; Suharsono, 2011), 
penurunan hasil kedelai akibat serangan hama ulat grayak dapat mencapai $90 \%$, tergantung pada fase pertumbuhan dan waktu serangan (Suharsono et al., 2007; Marwoto \& Suharsono, 2008) maupun varietas yang digunakan (Adie et al., 2012). Hal tersebut mengindikasikan bahwa ulat grayak merupakan hama potensial merugikan yang perlu mendapatkan penanganan secara bijaksana.

Tingkat ketahanan suatu varietas terhadap hama tertentu adalah bersifat relatif, karenanya pendekatan pengukuran ketahanan dapat didasarkan pada tingkat kepekaan dari suatu varietas unggul yang digunakan sebagai standar perbaikan. Identifikasi yang dilakukan oleh Igita et al. (1996) tidak satupun tanaman kedelai asal Indonesia yang bereaksi tahan terhadap ulat grayak, termasuk Wilis merupakan varietas yang berdaya hasil tinggi dan memiliki penyebaran yang cukup luas (Heriyanto, 2012). Berdasarkan tingkat kepekaan yang terdapat pada varietas Wilis dapat dijadikan sebagai kriteria perbaikan ketahanan suatu varietas terhadap ulat grayak. Galur-galur yang merupakan hasil persilangan antara genotipe tahan dengan varietas unggul diharapkan menghasilkan galur yang memiliki ketahanan sekaligus berproduksi tinggi. Tersedianya varietas kedelai tahan terhadap hama utama diharapkan mampu mempertahankan stabilitas hasil kedelai.

Beberapa hasil penelitian melaporkan bahwa hasil kajiannya tentang penggunaan pupuk $\mathrm{N}$ sebesar 112,5 $\mathrm{kg}$ urea/ha dapat meningkatkan perkembangan larva $S$. litura; durasi larva, terutama pada instar IV, VI, prepupa dan durasi seluruh larva dibandingkan pemberian pupuk $37,5 \mathrm{~kg} / \mathrm{h}$ a pada tanaman kedelai (Hartati, 2009). Artinya, pemberian pupuk yang berbeda berpengaruh nyata terhadap perkembangan ulat grayak pada stadia tertentu.

Mekanisme ketahanan tanaman terhadap hama dapat disebabkan karena faktor antibiosis (Komatsu et al., 2004). Ketahanan antibiosis merupakan mekanisme ketahanan tanaman yang disebabkan oleh adanya zat kimia tertentu yang mampu menghambat bahkan mematikan serangga hama. Menurut Singh (1986) terganggunya proses metabolisme fisiologis larva akibat adanya faktor antibiosis dapat berupa kematian larva terutama pada instar awal, pengurangan ukuran dan berat larva, kematian sebelum mencapai fase dewasa atau terganggunya siklus hidup dari larva itu sendiri. Dengan demikian pengukuran uji antibiosis dapat berdasar pada perubahan yang terjadi pada larva akibat mengkonsumsi daun dari setiap galur kedelai yang akan diuji. Penelitian bertujuan untuk mengetahui tingkat toleransi galur kedelai terhadap serangan ulat grayak.

\section{METODE PENELITIAN}

Tempat dan Waktu. Penelitian ini dilakukan di rumah kasa dan di Laboratorium Pemuliaan Balitkabi Malang pada bulan Februari 2011.

Pengujian. Penelitian terdiri dari dua bagian kegiatan yang bertujuan untuk mengetahui intensitas kerusakan daun dan pengaruh daun kedelai terhadap aspek biologi ulat grayak. Materi yang diuji kedua penelitian ini adalah galur kedelai hasil persilangan tunggal yang telah mencapai homosigot secara fenotipik yaitu Shr/W-C60,Aochi/Wil-60, 9837/K-D-8-185, 9837/K-D-3-185-95, W/9837-D-6-220, 9837/K-D-3-185-82, 9837/W-D-5211, GI, G100H dan varietas Wilis.

Penelitian di rumah kasa dirancang menggunakan acak kelompok yang diulang sebanyak tiga kali, uji analisis beda nyata terkecil (BNT) dilakukan jika hasil analisi uji $\mathrm{F}$ nyata $\geq 95 \%$. Media tanam yang dipergunakan adalah pot plastik $(\varnothing 18 \mathrm{~cm})$ yang telah terisi tanah, ditanam dua biji per pot dan dipelihara secara intensif. Saat tanaman berumur 27 hari, tanaman disungkup dengan kurungan kasa ( 2 × 2 × 2 m). Satu sungkup merupakan satu ulangan yang berisi 10 pot (materi yang di uji), sehingga seluruhnya terdapat tiga kurungan kasa. Penyusunan tanaman pada pot diatur sedemikian rupa supaya daun antar tanaman kedelai saling bersentuhan sehingga memungkinkan bagi larva untuk memilih daun tanaman kedelai yang disukai secara bebas. Selanjutnya tanaman pada pot yang berisi dua tanaman diinvestasikan larva ulat grayak instar I masingmasing sebanyak 5 ekor larva, sehingga dalam satu pot berjumlah 10 ekor larva. Bahan larva ulat grayak yang dinvestasi ke tanaman merupakan hasil pembiakan melalui telur ulat grayak yang diperoleh dari pertanaman kedelai di lapang. Telur-telur ulat grayak ditempatkan pada kotak kurungan dipelihara hingga menjadi menjadi imago. Selama periode pembiakan diberi makan daun jarak dan dijaga kehidupannya secara intensif. Selanjutnya, telur imago yang telah menetas menjadi stadia larva instar I digunakan sebagai bahan investasi dalam kegiatan penelitian.

Variabel yang diamati adalah intensitas kerusakan daun tanaman (\%) pada umur 4, 8, 12 dan 16 hari setelah investasi (HSI). Intensitas kerusakan daun dihitung mengikuti cara yang dilakukan oleh Rusdy (2009), Leatemia \& Rumthe (2011), Sembiring et al. (2013), dan Luhukay et al. (2013) dengan rumus sebagai berikut:

$$
\mathrm{I}=\frac{\sum(\mathrm{n} \times \mathrm{v})}{\mathrm{Z} \times \mathrm{N}} \times 100 \%
$$


Keterangan:

$\mathrm{I}=$ intensitas serangan

$\mathrm{n}=$ jumlah daun dalam tiap kategori serangan

$\mathrm{v}=$ nilai skala dari tiap kategori serangan (1-4)

$\mathrm{Z}=$ nilai skala dari kategori serangan tertinggi

$\mathrm{N}=$ jumlah daun yang diamati

Skala serangan:

$0=$ tidak ada serangan

$1=$ luas daun yang dimakan mencapai $1-25 \%$

2 = luas daun yang dimakan mencapai $26-50 \%$

$3=$ luas daun yang dimakan mencapai $51-75 \%$

4 = luas daun yang dimakan mencapai $76-100 \%$

Penelitian bagian lainnya dilakukan di Laboratorium Pemuliaan Balitkabi. Penelitian bertujuan untuk mengetahui pengaruh tanaman kedelai terhadap aspek biologi ulat grayak. Materi yang diuji sama dengan penelitian di atas. Untuk pengujiannya dibutuhkan daun buku ketiga dari tanaman kedelai pada umur 27 hari setelah tanam (HST) pada masing-masing materi (galur dan varietas Wilis). Penelitian dirancang menggunakan acak lengkap yang diulang tiga kali, uji analisis beda nyata terkecil (BNT) dilakukan jika hasil analisis uji $\mathrm{F}$ nyata pada taraf $95 \%$.

Pelaksanaan Penelitian. Satu daun buku ketiga pada setiap materi ditempatkan pada cawan Petri berdiameter $15 \mathrm{~cm}$ yang telah dilapisi kertas saring yang basah air (lembab), dan ini kemudian disebut sebagai perlakuan. Setiap perlakuan diinfestasi satu larva ulat grayak yang baru menetas (neonate). Jika daun yang dimakan ulat grayak telah habis, maka dilakukan penggantian daun dan kertas saring yang ada pada cawan Petri serta dijaga kelembabannya. Penggantian daun dilakukan secara bersamaan untuk setiap perlakuan hingga periode pra pupa.

Variabel Pengamatan. Variabel yang diamati dalam penelitian ini adalah: berat larva (mg) pada umur 3, 6 dan 9 setelah infestasi; umur stadia larva (hari) yang dihitung mulai instar 1 (neonate) hingga instar 5 akhir; umur stadia pupa (hari) yang dihitung mulai instar 5 akhir hingga menjadi pupa (sebelum membentuk imago); berat pupa (mg); diameter pupa (mm), diukur bagian tengah pupa; panjang pupa $(\mathrm{cm})$, diukur mulai ujung torak hingga ujung ovipositor; karakter daun meliputi luas daun tanaman $\left(\mathrm{cm}^{2}\right)$, tebal $(\mathrm{mm})$, kerapatan trikoma $\left(4 \mathrm{~mm}^{2}\right)$, panjang trikoma (mm) saat tanaman berumur 27 HST.

\section{HASIL DAN PEMBAHASAN}

Hasil penelitian menunjukkan bahwa intensitas kerusakan daun akibat ulat grayak beragam antar galur, dan intensitas kerusakan daun meningkat dengan semakin bertambahnya umur larva (Tabel 1). Rata-rata intensitas kerusakan daun pada umur empat, delapan, 12 dan 16 hari setelah investasi (HSI) berturut-turut

Tabel 1. Intensitas kerusakan daun oleh ulat grayak dari 10 galur harapan kedelai

\begin{tabular}{clcccc}
\hline \multirow{2}{*}{ No } & \multirow{2}{*}{ Nama galur harapan } & \multicolumn{4}{c}{ Intensitas kerusakan daun (\%) } \\
\cline { 3 - 6 } & & 4 HSI & 8 HSI & $12 \mathrm{HSI}$ & $16 \mathrm{HSI}$ \\
\hline 1 & Shr/W-C-60 & $16,86 \mathrm{bcd}$ & $28,96 \mathrm{~b}$ & $40,31 \mathrm{~b}$ & $54,39 \mathrm{~b}$ \\
2 & Aochi/Wil-60 & $11,43 \mathrm{bc}$ & $33,86 \mathrm{bc}$ & $50,36 \mathrm{bc}$ & $66,80 \mathrm{bcd}$ \\
3 & $9837 /$ K-D-8-185 & $10,90 \mathrm{bc}$ & $29,51 \mathrm{~b}$ & $56,52 \mathrm{~cd}$ & $71,90 \mathrm{bcd}$ \\
4 & $9837 /$ K-D-3-185-95 & $17,46 \mathrm{~cd}$ & $31,43 \mathrm{bc}$ & $53,51 \mathrm{bcd}$ & $75,83 \mathrm{~cd}$ \\
5 & W/9837-D-6-220 & $10,12 \mathrm{~b}$ & $22,92 \mathrm{~b}$ & $42,91 \mathrm{bc}$ & $58,10 \mathrm{bc}$ \\
6 & 9837/K-D-3-185-82 & $13,06 \mathrm{bcd}$ & $28,34 \mathrm{~b}$ & $49,61 \mathrm{bc}$ & $65,33 \mathrm{bc}$ \\
7 & $9837 /$ W-D-5-211 & $19,52 \mathrm{~d}$ & $32,33 \mathrm{bc}$ & $50,32 \mathrm{bc}$ & $63,34 \mathrm{bc}$ \\
8 & GI & $13,09 \mathrm{bcd}$ & $43,00 \mathrm{c}$ & $66,05 \mathrm{~d}$ & $85,17 \mathrm{~d}$ \\
9 & G100H & $2,89 \mathrm{a}$ & $7,73 \mathrm{a}$ & $12,39 \mathrm{a}$ & $30,30 \mathrm{a}$ \\
10 & Wilis & $13,30 \mathrm{bcd}$ & $34,86 \mathrm{bc}$ & $50,32 \mathrm{bc}$ & $64,06 \mathrm{bc}$ \\
& Rata-rata & 12,87 & 29,29 & 47,23 & 63,52 \\
& BNT 5\% & 7,11 & 12,38 & 14,95 & 19,16 \\
\hline
\end{tabular}

HSI = hari setelah investasi. Angka yang diikuti huruf yang sama pada kolom yang sama menunjukkan hasil yang tidak berbeda nyata berdasarkan uji BNT pada taraf 5\%. 
adalah 12,87; 29,29; 47,23 dan 63,52\% (Tabel 1). Intensitas kerusakan daun pada stadia larva antara 0 hingga empat, empat hingga delapan, delapan hingga 12 dan 12 hingga 16 HSI berturut-turut 12,9; 16,4; 17,9 dan $16,9 \%$. Hal ini menunjukkan bahwa stadia larva ulat grayak umur 8 hingga 12 HSI memiliki intensitas kerusakan daun atau daya makan daun tertinggi. Hasil ini memberi indikasi bahwa untuk pengendalian ulat grayak harus dilakukan sebelum periode puncak perkembangan stadia larva.

Variabel umur, berat, diameter maupun panjang pupa tidak berbeda nyata antar galur, sebaliknya pada umur larva (Tabel 2). Hal ini menunjukkan bahwa larva yang diberi pakan daun dari galur yang berbeda memiliki perbedaan umur larva. Larva ulat grayak yang diberi perlakuan pakan daun asal galur $\mathrm{G} 100 \mathrm{H}$ memiliki umur larva hingga 18 hari, sedangkan larva yang diberi pakan daun dari galur lainnya umur larva sekitar 13 hari. Kemungkinan hal ini karena pakan daun kedelai G100H tidak disukai larva ulat grayak, atau penyebabnya adalah proses terganggunya sistem pencernan padaperiode stadia larva. Menurut Harborne (1987) bahwa pada tanaman terdapat kandungan kimia tertentu yang dapat bereaksi dengan protein membentuk kopolimer (gabungan dua senyawa yang telah mengalami reaksi) mantap yang tidak larut dalam air. Salah satu kandungan kimia pada tanaman dapat berupa senyawa tanin, merupakan penghambat enzim yang kuat bila terikat pada protein sehingga mempunyai sifat astrigensi (Manitto, 1991), yaitu kemampuan mengkerutkan mulut umumnya pada serangga (Salisbury \& Ross, 1992). Apabila tanin berikatan secara komplek dengan protein dapat mempengaruhi jaringan tanaman yang dapat dicerna serta menurunkan ikatan komplek enzim-enzim pencernaan atau bertindak sebagai antifedan (zat penolak makan) serangga (Smith et al., 1992; Wassimi et al., 1988). Namun, pada penelitian ini tidak dianalisa kandungan kimia tertentu pada daun tanaman kedelai, sehingga hal ini merupakan dugaan awal. Hasil penelitian yang dilakukan oleh Kesumawaty (2003) dilaporkan bahwa umur larva dan berat pupa merupakan salah satu dari karakter biologi ulat grayak yang paling dipengaruhi oleh perbedaan pakan daun kedelai. Variabel lainnya menunjukkan bahwa pengaruh pakan daun kedelai terhadap berat larva pada umur 3 HSI tidak berbeda nyata antar galur, tetapi pada umur 6 dan 9 HSI berbeda nyata. Berat larva yang diberi pakan daun dari galur G100H pada umur 9 HSI hanya $1,147 \mathrm{mg}$, jauh lebih rendah dibandingkan berat larva yang mendapat pakan daun kedelai dari galur harapan lainnya (Tabel 3).

Pengetahuan tentang faktor penentu ketahanan suatu galur harapan terhadap hama tertentu sangat penting, selain dapat digunakan dalam penyusunan strategi pengendalian, juga bermanfaat untuk meningkatkan ketahanan tanaman terhadap hama tertentu, sekaligus dapat digunakan sebagai kriteria

Tabel 2. Biologi ulat grayak asal pakan daun pada 10 galur harapan kedelai

\begin{tabular}{|c|c|c|c|c|c|c|}
\hline \multirow{2}{*}{ No } & \multirow{2}{*}{ Nama galur harapan } & \multicolumn{2}{|c|}{ Umur stadia (hari) } & \multirow{2}{*}{$\begin{array}{l}\text { Berat pupa } \\
\quad(\mathrm{mg})\end{array}$} & \multirow{2}{*}{$\begin{array}{c}\text { Diameter } \\
\text { pupa }(\mathrm{mm})\end{array}$} & \multirow{2}{*}{$\begin{array}{c}\text { Panjang } \\
\text { pupa }(\mathrm{cm})\end{array}$} \\
\hline & & Larva & Pupa & & & \\
\hline 1 & Shr/Wil-C-60 & $13,29 \mathrm{~b}$ & 8,14 & 0,37 & 5,90 & 1,90 \\
\hline 2 & Aochi/Wil-60 & $13,29 \mathrm{~b}$ & 8,29 & 0,39 & 6,01 & 2,00 \\
\hline 3 & 9837/K-D-8-185 & $14,29 \mathrm{ab}$ & 8,29 & 0,35 & 5,96 & 1,90 \\
\hline 4 & 9837/K-D-3-185-95 & $13,29 \mathrm{~b}$ & 7,86 & 0,34 & 5,90 & 1,91 \\
\hline 5 & W/9837-D-6-220 & $13,14 \mathrm{~b}$ & 8,14 & 0,33 & 5,96 & 1,91 \\
\hline 6 & 9837/K-D-3-185-82 & $13,00 \mathrm{~b}$ & 8,00 & 0,34 & 5,73 & 1,94 \\
\hline 7 & $9837 / \mathrm{W}-\mathrm{D}-5-211$ & $12,29 \mathrm{a}$ & 7,86 & 0,35 & 5,90 & 1,84 \\
\hline 8 & GI & $13,14 \mathrm{~d}$ & 8,14 & 0,40 & 6,19 & 1,76 \\
\hline 9 & $\mathrm{G} 100 \mathrm{H}$ & $18,14 \mathrm{c}$ & 7,57 & 0,27 & 5,50 & 1,76 \\
\hline \multirow[t]{3}{*}{10} & Wilis & $12,14 \mathrm{a}$ & 7,57 & 0,34 & 5,71 & 1,93 \\
\hline & Rata-rata & 13,60 & 7,99 & 0,35 & 5,87 & 1,89 \\
\hline & BNT 5\% & 0,48 & $\operatorname{tn}$ & tn & tn & $\operatorname{tn}$ \\
\hline
\end{tabular}

$\mathrm{tn}=$ tidak nyata. Angka yang diikuti huruf yang sama pada kolom yang sama menunjukkan hasil yang tidak berbeda nyata berdasarkan uji BNT pada taraf $5 \%$. 
Tabel 3. Berat larva ulat grayak asal pakan daun pada 10 galur harapan kedelai

\begin{tabular}{clccc}
\hline & \multirow{2}{*}{ No } & & \multicolumn{3}{c}{ Berat larva (mg/ekor) } \\
\cline { 3 - 5 } & & 3 HSI & 6 HSI & 9 HSI \\
\hline 1 & Shr/W-C-60 & 0,022 & $0,463 \mathrm{bcde}$ & $1,818 \mathrm{ab}$ \\
2 & Aochi/Wil-60 & 0,026 & $0,549 \mathrm{de}$ & $2,455 \mathrm{c}$ \\
3 & $9837 /$ K-D-8-185 & 0,027 & $0,503 \mathrm{cde}$ & $2,340 \mathrm{c}$ \\
4 & $9837 /$ K-D-3-185-95 & 0,025 & $0,487 \mathrm{cde}$ & $2,088 \mathrm{bc}$ \\
5 & W/9837-D-6-220 & 0,027 & $0,410 \mathrm{bc}$ & $1,499 \mathrm{ab}$ \\
6 & $9837 /$ K-D-3-185-82 & 0,026 & $0,445 \mathrm{bcd}$ & $2,015 \mathrm{bc}$ \\
7 & 9837/W-D-5-211 & 0,024 & $0,354 \mathrm{ab}$ & $1,607 \mathrm{ab}$ \\
8 & GI & 0,028 & $0,550 \mathrm{de}$ & $1,501 \mathrm{ab}$ \\
9 & G100H & 0,022 & $0,323 \mathrm{a}$ & $1,147 \mathrm{a}$ \\
10 & Wilis & 0,027 & $0,536 \mathrm{cde}$ & $1,993 \mathrm{bc}$ \\
\hline & Rata-rata & 0,026 & 0,462 & 1,860 \\
\hline & BNT 5\% & tn & 0,11 & 0,72 \\
\hline
\end{tabular}

$\mathrm{tn}=$ tidak nyata. Angka yang diikuti huruf yang sama pada kolom yang sama menunjukkan hasil yang tidak berbeda nyata berdasarkan uji BNT pada taraf 5\%.

seleksi tak langsung. Penentuan dan pencarian kriteria seleksi tak langsung sangat penting, karena akan meningkatkan efisiensi program pemuliaan.

Di antara galur-galur yang diuji maka $\mathrm{G} 100 \mathrm{H}$ memiliki daun lebih tebal, trikoma yang lebih rapat, serta trikoma yang panjang (Tabel 4). Berkaitan dengan karakter-karakter tersebut menunjukkan bahwa galur G100H memiliki intensitas kerusakan daun yang terendah, berbeda dengan galur lainnya maupun dengan varietas cek Wilis. Norris \& Kogan (1980) mengemukakan bahwa karakter trikoma sebagai faktor pertahanan fisik terhadap ulat grayak ditentukan oleh kerapatan dan panjang trikoma. IAC-100 merupakan galur yang bertrikoma padat konsisten tahan terhadap serangan hama pemakan daun, terutama ulat grayak (Suharsono et al., 2008; Suharsono \& Adie, 2010), maupun G 100 H (Suharsono \& Suntono, 2007) hal ini membuktikan bahwa trikoma berperan dalam pertahanan terhadap serangan hama ulat grayak.

Karakter morfologi penentu ketahanan kedelai terhadap ulat grayak dikaji dengan analisis korelasi dari beberapa karakter morfologi daun dengan intensitas kerusakan daun maksimum yang dicapai setelah infestasi larva selama 16 hari (Tabel 5). Terdapat dua karakter morfologi daun yang berperan sebagai penentu ketahanan kedelai terhadap ulat grayak yakni kerapatan trikoma pada permukaan daun bagian atas dan panjang trikoma daun pada permukaan bawah daun, masingmasing dengan nilai $r=-0,753$ dan $r=-0,689$. Menilih hasil ini maka galur $\mathrm{G} 100 \mathrm{H}$ memiliki ketahatan terhadap ulat grayak dengan karakteristik bertrikoma padat dan panjang dibandingkan dengan galur lainnya maupun varietas cek Wilis. Adapun peran karakter ketebalan dan luas daun terhadap ketahanan kedelai terhadap ulat grayak relatif kecil.

Struktur daun kedelai nampaknya belum terlalu kuat menahan larva ulat grayak yang bertipe mulut menggigit dan mengunyah. Intensitas serangan pada daun tergantung pada populasi ulat grayak. Makin tinggi populasi ulat grayak makin tinggi intensitas serangan akibat aktivitas ulat mengkonsumsi daun kedelai sebagai sumber pakan (Suharsono, 2011). Kajian untuk tanaman serealia, Blum (1982) mengemukakan bahwa varietas sorgum yang tahan terhadap lalat bibit Atherigona varia, ditentukan oleh adanya daun-daun muda yang mempunyai dinding sel tebal, sehingga berpengaruh terhadap proses penggangguan sistem pencernaan. Pola yang sama juga ditemukan pada hama belalang hijau Melanoplus confusus yang tidak mampu mencerna daun rumput-rumputan (Panicum virgatu, Andropogon gerardi dan Schizachyrium scoparum).

Kerapatan trikoma daun permukaan atas dan bawah berkorelasi nyata positif, pola yang sama ditemukan juga pada karakter panjang trikoma. Fakta ini sekaligus mengindikasikan bahwa penilaian ketahanan kedelai terhadap ulat grayak dapat ditilik dari kerapatan trikoma daun dan atau panjang trikoma. Seperti hasil penelitian Hendrival et al. (2013) yang menyimpulkan 
Tabel 4. Karakter morfologi daun dari 10 galur harapan kedelai

\begin{tabular}{|c|c|c|c|c|c|c|c|}
\hline \multirow[b]{2}{*}{ No } & \multirow[b]{2}{*}{ Nama galur harapan } & \multirow{2}{*}{$\begin{array}{l}\text { Ketebalan } \\
\text { daun (mm) }\end{array}$} & \multicolumn{2}{|c|}{ Kerapatan trikoma/4 mm² } & \multicolumn{2}{|c|}{ Panjang trikoma (mm) } & \multirow{2}{*}{$\begin{array}{c}\text { Luas } \\
\text { daun/ } \\
\text { tanaman } \\
\left(\mathrm{cm}^{2}\right)\end{array}$} \\
\hline & & & $\begin{array}{l}\text { Bagian } \\
\text { permukaan } \\
\text { atas }\end{array}$ & $\begin{array}{l}\text { Bagian } \\
\text { permukaan } \\
\text { bawah }\end{array}$ & $\begin{array}{c}\text { Bagian } \\
\text { permukaan } \\
\text { atas }\end{array}$ & $\begin{array}{c}\text { Bagian } \\
\text { permukaan } \\
\text { bawah }\end{array}$ & \\
\hline 1 & Shr/W-C-60 & 0,80 cdef & $15,33 \mathrm{a}$ & $11,00 \mathrm{ab}$ & $0,52 \mathrm{~b}$ & $0,52 \mathrm{~b}$ & $32,04 \mathrm{~cd}$ \\
\hline 2 & Aochi/Wil-60 & $0,70 \mathrm{abcd}$ & $15,67 \mathrm{a}$ & $10,00 \mathrm{a}$ & $1,00 \mathrm{c}$ & $0,87 \mathrm{c}$ & 59,37 e \\
\hline 3 & 9837/K-D-8-185 & $0,67 \mathrm{abc}$ & $15,33 \mathrm{a}$ & $16,00 \mathrm{c}$ & $0,57 \mathrm{~b}$ & $0,57 \mathrm{~b}$ & $25,44 \mathrm{bc}$ \\
\hline 4 & 9837/K-D-3-185-95 & $0,67 \mathrm{abc}$ & $14,67 \mathrm{a}$ & $15,67 \mathrm{bc}$ & $0,63 \mathrm{~b}$ & $0,60 \mathrm{~b}$ & $51,65 \mathrm{e}$ \\
\hline 5 & W/9837-D-6-220 & $0,63 \mathrm{ab}$ & 18,67 a & $16,33 \mathrm{c}$ & $0,57 \mathrm{~b}$ & $0,80 \mathrm{c}$ & $36,95 \mathrm{~d}$ \\
\hline 6 & 9837/K-D-3-185-82 & 0,87 def & $14,67 \mathrm{a}$ & $15,67 \mathrm{bc}$ & $0,60 \mathrm{~b}$ & $0,45 \mathrm{~b}$ & $35,85 \mathrm{~d}$ \\
\hline 7 & 9837/W-D-5-211 & 0,90 ef & 15,67 a & $15,67 \mathrm{bc}$ & $1,40 \mathrm{~d}$ & $1,10 \mathrm{~d}$ & $36,04 \mathrm{~d}$ \\
\hline 8 & GI & 0,77 bcde & $15,00 \mathrm{a}$ & $10,00 \mathrm{a}$ & $0,23 \mathrm{a}$ & $0,10 \mathrm{a}$ & $20,72 \mathrm{a}$ \\
\hline 9 & $\mathrm{G} 100 \mathrm{H}$ & $0,97 \mathrm{f}$ & $25,00 \mathrm{~b}$ & $29,00 \mathrm{e}$ & $1,07 \mathrm{c}$ & $1,10 \mathrm{~d}$ & $55,23 \mathrm{e}$ \\
\hline \multirow[t]{3}{*}{10} & Wilis & $0,57 \mathrm{a}$ & $16,00 \mathrm{a}$ & $22,67 \mathrm{~d}$ & $0,47 \mathrm{~b}$ & $0,50 \mathrm{~b}$ & $29,96 \mathrm{~cd}$ \\
\hline & Rata-rata & 0,75 & 16,60 & 16,20 & 0,70 & 0,66 & 38,32 \\
\hline & BNT 5\% & 0,17 & 5,82 & 4,29 & 0,23 & 0,16 & 8,48 \\
\hline
\end{tabular}

BNT = beda nyata terkecil. Angka sekolom yang diikuti oleh huruf yang sama tidak berbeda nyata menurut uji BNT $5 \%$.

Tabel 5.Korelasi antara intensitas kerusakan daun 16 HSI dengan karakter morfologi daun

\begin{tabular}{lccllll}
\hline \multicolumn{1}{r}{ Sifat } & $\begin{array}{c}\text { Kerusakan } \\
\text { daun 16 HSI }\end{array}$ & TBDN & KR-A & KR-B & PJ-A & PJ-B \\
\hline TBDN & 0,101 & 1,000 & & & & \\
KR-A & $-0,753^{* *}$ & $-0,473$ & 1,000 & & & \\
KR-B & $-0,629$ & $-0,335$ & $0,744^{*}$ & 1,000 & & \\
PJ-A & $-0,561$ & $-0,073$ & 0,528 & 0,045 & 1,000 & \\
PJ-B & $-0,689^{*}$ & $-0,310$ & $0,783^{* *}$ & 0,291 & $0,910^{* *}$ & 1,000 \\
LD & 0,451 & $-0,159$ & 0,082 & $-0,361$ & 0,129 & 0,151 \\
\hline
\end{tabular}

*nyata pada $\mathrm{p}=0,05 ; * *$ = nyata pada $\mathrm{p}=0,01 ; \mathrm{TBDN}=$ tebal daun; KR-A = kerapatan trikoma daun bagian permukaan atas; $\mathrm{KR}-\mathrm{B}=$ kerapatan trikoma daun bagian permukaan bawah; $\mathrm{PJ}-\mathrm{A}=$ panjang trikoma daun bagian permukaan atas; $\mathrm{PJ}-\mathrm{B}=$ panjang trikoma daun bagian permukaan bawah; $\mathrm{LD}=$ luas daun/tanaman.

bahwa trikoma pada daun kedelai berperan terhadap ketahahanan morfologis terhadap hama ulat grayak. Berdasarkan aspek kepraktisan mengukur kepadatan trikoma lebih mudah dibandingkan dengan panjang trikoma, karenanya karakter kepadatan trikoma, baik pada daun pada permukaan atas maupun bawah, dapat dipertimbangkan digunakan sebagai kriteria seleksi ketahanan kedelai terhadap hama ulat grayak. Berdasarkan serangkaian penelitian ini, maka galur G100H memiliki trikoma padat di daun dan berkriteria tahan serangan ular grayak. Artinya kewaspadaan diperlukan untuk mengantisipasi infestasi ulat grayak, agar kerugian hasil dapat dihindari.

\section{SIMPULAN}

Untuk menilai tingkat ketahanan tanaman kedelai terhadap ulat grayak dapat ditilik dari kerapatan trikoma dan atau panjang trikoma daun. Galur G100H berkriteria tahan serangan ulat grayak dibandingkan dengan galurgalur yang diuji maupun varietas cek Wilis. 


\section{SANWACANA}

Terima kasih kepada DIPA Badan Litbang Pertanian yang membiayai penelitian dan kepada Toni (teknisi pemuliaan Balitkabi Malang) yang membantu serangkaian penelitian.

\section{DAFTAR PUSTAKA}

Adie MM, Krisnawati A, \& Mufidah AZ. 2012. Derajat ketahanan genotipe kedelai terhadap hama ulat grayak. Dalam: Rahmianna AA, Yusnawan E, Taufiq A, Sholihin, Suharsono, Sundari T, \& Hermanto (Eds.). Prosiding Seminar Hasil Penelitian Tanaman Aneka Kacang dan Umbi. Peningkatan Daya Saing dan Implementasi Pengembangan Komoditas Kacang dan Umbi Mendukung Pencapaian Empat Sukses Pembangunan Pertanian. pp. 29-36. Pusat Penelitian dan Pengembangan Tanaman Pangan, Malang. 5 Juli 2012.

Arifin M \& Koswanudin D. 2010. Alternatif teknologi pengendalian ulat grayak pada kedelai dengan berbagai jenis insektisida biorasional. Dalam: Kardinan A, Laba IW, Kartohardjono A, \& Harnoto (Eds.). Prosiding Seminar Nasional VI PEI. Peranan Entomologi dalam Mendukung Pengembangan Pertanian Ramah Lingkungan dan Kesehatan Masyarakat. pp. 419-434. Bogor. 24 Juni 2010.

Blum A. 1982. Evidence for genetic variability in drought resistance and its applications in plant breeding. In: IRRI. Drought Resistance in Crops with Emphasis on Rice. pp. 56-68. Publisher IRRI, Los Banos.

Harborne JB. 1987. Metode Fitokimia (Penuntun Cara Modern Menganalisis Tumbuhan). 2. ITB. Bandung. pp. 102-109.

Hartati S. 2009. Biologi Spodoptera litura F. (Lepidoptera: Noctuidae) pada Tanaman Kedelai dengan Dosis Pupuk Nitrogen yang Berbeda. http://uripsantoso.wordpress.com/2009/07/24/ biologi-spodoptera-litura-f-lepidoptera-noctuidaepada-tanaman-kedelai-dengan-dosis-pupuknitrogen-yang-berbeda/. Diakses 6 Desember 2011.
Hendrival, Latifah, \& Hayu R. 2013. Perkembangan Spodoptera litura F. (Lepidoptera: Noctuidae) pada kedelai. J. Floratek 8: 88-100.

Heriyanto. 2012. Upaya percepatan respon petani dalam peningkatan kontribusi varietas unggul kedelai terhadap pendapatan daerah Jawa Timur. $J$. Cakrawala 6(2): 114-128.

Igita K, Adie MM, Suharsono, \& Tridjaka. 1996. Second brief report: Method of cultivation of soybean in cropping systems with low input (pesticide) in Indonesia. RILET-JIRCAS, Malang.

Kesumawaty R. 2003. Hubungan morfologi daun beberapa genotipe kedelai dengan ketahanan ulat grayak. Tesis. Universitas Brawijaya, Malang.

Komatsu K, Okuda S, Takashi M, \& Madsunaga R. 2004. Antibiotic effect and insect-resistant soybean on common armyworm (Spodoptera litura) and its inheritance. Breed. Sci. 54: 2732.

Leatemia JA \& Rumthe RY. 2011. Studi kerusakan akibat serangan hama pada tanaman pangan di Kecamatan Bula, Kabupaten Seram Bagian Timur, Propinsi Maluku. J. Agroforestri 6(1): 5356.

Luhukay JN, Uluputty MR, \& Rumthe RY. 2013. Respons lima varietas kubis (Brassica oleracea 1.) terhadap serangan hama pemakan daun Plutella xylostella (Lepidoptera: Plutellidae). Agrologia: J. Ilmu Budidaya Tan. 2(2): 164169.

Manitto P. 1991. Biosintesa Produk Alami. Diterjemahkan oleh Sammes PG. John Wiley \& Sons, New York.

Marwoto \& Suharsono. 2008. Strategi dan komponen teknologi pengendalian ulat grayak (Spodoptera litura Fabricius) pada tanaman kedelai. $J$. Litbang Pertanian 27(4): 131-136.

Norris DM \& Kogan M. 1980. Biochemical and morphological bases of resistance. In: Maxwell FG \& Jennings PR (Eds.). Breeding plants Resistant to Insects. pp. 23-60. John Wiley and Sons, New York. 
Ravishankar BS \& Venkatesha MG. 2010. Effectiveness of slnpv of Spodoptera litura (Fab.) (Lepidoptera: Noctuidae) on different host plants. J. Biopestisida 3: 168-171.

Rusdy A. 2009. Efektivitas ekstrak daun mimba dalam pengendalian ulat grayak (Spodoptera litura F.) pada tanaman selada. J. Floratek 4: 41-54.

Salisbury FB \& Ross CW. 1992. Plant Physiology. $4^{\text {th }}$, Wadsworth Publishing Co., Adivision of Wadsworth, Inc.

Sembiring N, Tarigan MN, \& Lisnawita. 2013. Tingkat serangan ulat kantong Metisa plana Walker (Lepidoptera: Psychidae) terhadap umur tanaman kelapa sawit (Elaeis guineensis Jacq.) di kebun Matapao PT. Socfin Indonesia. $J$. Agroekoteknologi 1(4): 135-143

Singh DP. 1986. Breeding for resistance to disease and insect pests. Crop Protection Monographs Springer-Verlag, Berlin.

Smith WC, McCarty Jr JC, Altamarino TP, Lege KE, Schuster MF, Phillips JR, \& Lopez JD.1992. Condensed tannins in cotton and bollworm budworm (Lepidoptera: Noctuidae) resistance. $J$. Econ. Entomol. 85(6): 2211-2217.

Suharsono. 2011. Kepekaan galur kedelai toleran jenuh air terhadap ulat grayak Spodoptera litura F. Suara Perlindungan Tanaman 1(3): 13-22.
Suharsono \& Adie MM. 2010. Identifikasi sumber ketahanan aksesi plasma nutfah kedelai untuk ulat Spodoptera litura F. Buletin Plasma Nutfah 16(1): 29-37.

Suharsono \& Suntono. 2007. Efektivitas beberapa jenis insektisida kimia dan galur tahan untuk mengendalikan hama perusak daun. Hasil Penelitian Tahun 2015. Balitkabi, Malang.

Suharsono, Rahayu M, Hardaningsih S, Tengkano W, Indiati SW, Marwoto, Bedjo, \& Baliadi Y. 2007. Perbaikan dan evaluasi komponen teknologi pengendalian hama dan penyakit terpadu (PHT) pada tanaman kedelai. Laporan Akhir Hasil Penelitian Tahun 2007. Pusat Penelitian dan Pengembangan Tanaman Pangan, Bogor.

Suharsono, Rahayu M, Hardaningsih S, Tengkano W, Indiati SW, Marwoto, Bedjo, \& Baliadi Y. 2008. Perbaikan dan evaluasi komponen teknologi pengendalian hama dan penyakit terpadu (PHT) pada tanaman kedelai. Laporan Akhir Hasil Penelitian Tahun 2008. Pusat Penelitian dan Pengembangan Tanaman Pangan, Bogor

Wassimi NN, Hosfield GL, \& Uebersax MA. 1988. Combining ability of tanin content and protein characteristics of row and cooked dry beans. Crop Sci. 28(3): 452-458. 